Pembinaan Karakter Siswa Kelas IX melalui Kegiatan Membaca Kritis di MTs Nurul Hikmah dan SMP Driewanti Bekasi, Jawa Barat

\author{
*Nicky Rosadi ${ }^{1}$, Priyono ${ }^{2}$, Sigit Widiyarto ${ }^{3}$ \\ Universitas Indraprasta PGRI \\ *nicky.rosadi@unindra.ac.id
}

\begin{abstract}
Abstrak
Pembelajaran Bahasa Indonesia tidak sekadar mencapai keterampilan berbahasa Indonesia, tetapi mengarah pada peningkatan kemampuan berpikir kritis dan kreatif. Berkaitan dengan hal tersebut, salah satu cara untuk meningkatkan kemampuan berpikir kritis dan kreatif melalui kegiatan membaca. Oleh karena itu, salah satu jenis keterampilan membaca yang dapat meningkatkan kemampuan berpikir kritis adalah keterampilan membaca kritis. Tujuan pengabdian masyarakat ini ialah untuk membina karakter siswa melalui kegiatan membaca kritis. Kegiatan pengabdian masyarakat ini akan diadakan di dua sekolah yang ada di Kota Bekasi. Peserta kegiatan ini adalah siswa-siswi kelas IX di MTs Nurul Hikmah dan SMP Driewanti Bekasi. Di sekolah ini terdapat dua kelas rombongan belajar kelas IX, dengan jumlah siswa sebanyak 42 anak.
\end{abstract}

Kata Kunci: pembinaan karakter, membaca kritis

\title{
Character Development for Class IX Students through Critical Reading Activities at MTs Nurul Hikmah and Driewanti Middle School Bekasi, West Java
}

\begin{abstract}
Indonesian Language Learning does not merely achieve Indonesian language skills, but leads to an increase in the ability to think critically and creatively. In this regard, one way to improve the ability to think critically and creatively through reading activities. Therefore, one type of reading skills that can improve critical thinking skills is critical reading skills. The aim of community service is to foster student character through critical reading activities. This community service activity will be held in two schools in the city of Bekasi. Participants in this activity were students of class IX at MTs Nurul Hikmah and Driewanti Middle School Bekasi. In this school there are two classes of class IX class, with 42 students.
\end{abstract}

Keywords: character building, critical reading

\section{PENDAHULUAN}

Pengajaran bahasa Indonesia terdiri dari beberapa aspek kemampuan berbahasa dan bersastra. Kemampuan berbahasa dan bersastra meliputi empat aspek keterampilan, yaitu keterampilan membaca, menulis, menyimak, dan berbicara, salah satu dari keempat keterampilan itu yakni keterampilan membaca. Keterampilan membaca menjadi salah satu pembelajaran yang tidak hanya mengasah kemampuan memahami pesan, tetapi melatih kemampuan berpikir siswa. Melalui keterampilan ini, siswa mengolah dan mengasah informasi dari bacaan yang sedang dibaca dan menghubungkan bacaan dengan informasi terdahulu yang telah diperolehnya. Siswa juga dapat memahami ilmu pengetahuan dan mengikuti perkembangan ilmu pengetahuan.

Menilik hal tersebut, kemampuan membaca merupakan kemampuan yang penting dan harus dimiliki oleh siswa untuk dapat bersaing dan mengikuti perkembangan zaman. Berkaitan dengan hal tersebut, dalam laporan PISA tahun 2015 menyebutkan bahwa 
kemampuan membaca siswa Indonesia berada di urutan ke-62 dari 70 negara hasil survei PISA. Hal tersebut menunjukkan bahwa kemampuan berpikir siswa Indonesia melalui keterampilan membaca perlu mendapatkan perhatian. Salah satu upaya dalam meningkatkan kemampuan membaca siswa Indonesia, pemerintah merancang program GLS (Gerakan Literasi Sekolah) yang bertujuan untuk membangun budaya literasi sejak dini melalui pembiasan membaca di sekolah. Hal tersebut tentu sejalan dengan yang dikemukakan oleh Alwasilah (2008: 149), bahwa pendidikan bahasa sebaiknya diniatkan sebagai pembangunan literasi kritis.

Literasi kritis yang dimaksud Alwasilah tersebut mencakup sikap dan keterampilan yang ktitis dan analitis untuk memahami dan menginterpretasi teksteks ujaran maupun teks tertulis. Mengenai literasi kritis, Sastromihardjo menyatakan bahwa pembelajaran bahasa Indonesia tidak sekadar mencapai keterampilan berbahasa Indonesia, tetapi mengarah pada peningkatan kemampuan berpikir kritis dan kreatif. Berkaitan dengan pemaparan tersebut, salah satu cara untuk meningkatkan kemampuan berpikir kritis dan kreatif melalui kegiatan membaca. Oleh karena itu, salah satu jenis keterampilan membaca yang dapat meningkatkan kemampuan berpikir kritis adalah keterampilan membaca kritis.

Keterampilan membaca kritis perlu mendapatkan perhatian, mengingat sistem pendidikan Indonesia saat ini menggunakan kurikulum 2013 revisi yang menitikberatkan pembelajaran bahasa Indonesia pada teks. Keterampilan ini dapat membantu siswa untuk lebih memahami jenis teks, tujuan penulis, dan pesan tersirat yang dikemukakan oleh penulis. Seperti yang dikemukakan oleh Harrison, bahwa berbahasa akan lebih penting dalam menentukan, mereproduksi dan mendukung hubungan kekuatan yang mendominasi dan mengontrol masyarakat, dan sejak praktik bahasa menjalankan di berbagai hal yang implisit daripada eksplisit, hal tersebut menjadi sangat penting untuk menemukan, mengidentifikasi, dan mengkritik praktik berbahasa tersebut.

Kemudahan siswa untuk memperoleh informasi dari berbagai sumber, baik media cetak maupun elektronik, dikhawatirkan akan memberikan dampak negatif bagi siswa, seandainya siswa tidak memiliki filter yang baik saat membaca dan memahami informasi tersebut. Hal tersebut dapat diminimalisasi melalui pembelajaran membaca kritis, karena keterampilan ini mengajarkan siswa untuk menganalisis dan mengevaluasi teks-teks, baik teks ujaran maupun teks tertulis yang hadir di sekitar kehidupannya. Hal ini sesuai dengan pernyataan Spears dan Wallace \& Way, bahwa keterampilan membaca kritis adalah kemampuan untuk menilai, mengevaluasi, dan mempertimbangkan gagasan penulis dengan cermat, serta mengaplikasikan alasan penilaiannya.

Membaca kritis merupakan kegiatan membaca yang kompleks, membaca keseluruhan isi buku, atau kegiatan membaca terbaik yang dapat dilakukan (Adler dan Doren, 2007: 20). Diharapkan, kemampuan membaca kritis yang dimiliki siswa dapat menjadi alat untuk menyaring informasi-informasi yang didapat agar sesuai dengan karakter bangsa Indonesia. 


\section{METODE}

Kegiatan pengabdian masyarakat ini dimulai dengan mengurus perizinan

Vol. 1, No. 1,

MARCH

2020,

pp. 8-12

e-ISSN:

XXXX-XXXX

Title

Character

Development

for Class IX

Students

through

Critical

Reading

Activities at

MTs Nurul

Hikmah and

Driewanti

Middle School

Bekasi, West

Java

Author

Nicky Rosadi ${ }^{1}$,

Priyono²,

Sigit Widiyarto $^{3}$ dan peninjauan daerah mitra yang dilakukan bulan Maret 2018, proses persiapan sosialisasi membaca kritis dengan menggunakan teks yang bernilai karakter dilakukan pada Awal April 2018. Pelaksanaan kegiatan pengabdian masyarakat dimulai minggu pertama sampai Mei 2018. Tempat kegiatan pengabdian masyarakat ini di MTs Nurul Hikmah Bekasi, yang beralamat di Jalan Rawa Tengah Kelurahan Cikiwul, Kota Bekasi, Jawa Barat dan SMP Driewanti di Jalan Driewanti, Pekayon Jaya, Bekasi Selatan, Jawa Barat.

Metode yang akan dilakukan dalam kegiatan ini adalah melalui beberapa tahap:

1. Observasi langsung. Observasi langsung yakni pengabdi langsung datang ke lokasi pengabdian untuk memperolah data. Hal ini kami lakukan pada saat menjelang maupun saat kegiatan berlangsung. Observasi berguna untuk mengetahui kebutuhan dan apa yang harus ditingkatkan. Observasi sangat penting untuk mewujudkan kesuksesan kegiatan pengabdian masyarakat itu sendiri.

2. Penyuluhan, yaitu tim pengabdi mengajarkan secara langsung cara membaca kritis kepada siswa-siswi yang akan dilakukan minimal tiga kali tatap muka agar siswa-siswi SMP lebih memahami konsep pembelajaran Bahasa Indonesia yang akan diajarkan.

Peserta kegiatan pengabdian masyarakat ini adalah siswa-siswi MTs Nurul Hikmah dan SMP Driewanti Bekasi. Pembimbing dalam kegiatan ini adalah dosen yang berada dalam Program Studi Ekonomi dan mampu pada bidangnya.

Pelaksanaan kegiatan ini dilakukan dalam tiga tahap, yaitu tahap persiapan, pelaksanaan, dan evaluasi. Tahap pertama adalah tahap persiapan. Pada tahap ini, tim melakukan survei pendahuluan dan wawancara awal terhadap guru serta beberapa siswa untuk mengetahui target kegiatan, kondisi siswa yang akan diberikan perlakuan, dan menyusun rancangan kegiatan yang akan dilakukan. Tahap persiapan selanjutnya, tim menyiapkan bahan-bahan yang akan dijadikan pembelajaran sebagai materi pengabdiaan masyarakat ini.

Tahap kedua yaitu tahap pelaksanaan. Kegiatan penyuluhan ini dilakukan tim dengan memberikan informasi kepada siswa mengenai penyampaian metode instruksi dalam membaca teks dan penyajian materi yang menarik serta menyenangkan.

Tahap pelaksanaan terakhir yaitu memberikan kesempatan siswa untuk latihan membaca kritis dengan menggunakan metode instruksi di dalam kelas. Tahap yang terakhir adalah tahapan evaluasi. Evaluasi kegiatan ini dilakukan terhadap proses kegiatan. Evaluasi proses berkaitan dengan kehadiran peserta, semangat, dan antusias peserta mengikuti kegiatan dan kerja sama yang terjalin selama proses pelaksanaan, serta tingkat pemahaman siswa setelah menerima MTs Nurul Hikmah and Driewanti Middle School Bekasi, West Java. KANGMAS: Karya Ilmiah Pengabdian Masyarakat, 1 (1). 8-12 
materi membaca kritis dengan menggunakan metode instruksi. Evaluasi proses dilakukan selama kegiatan berlangsung.

\section{HASIL DAN PEMBAHASAN}

Pelaksanaan kegiatan berlangsung mulai bulan Maret 2018. Pertemuan awal diperkenalkan tim abdimas. Para siswa juga dijelaskan pentingnya pelajaran bahasa Indonesia. Para siswa dipersilakan bertanya. Beberapa siswa bertanya terkait membaca dan jenisnya. Pertemuan berikutnya selama 45 x 2 membahas tentang membaca kritis. Pada pertemuan ini anak dilatih membaca kritis. Para siswa antusias untuk mengikuti kegiatan tersebut. Pertemuan berikutnya siswa diberi materi/teks dengan membaca secara kritis. Pada pertemuan keempat, diadakan evaluasi para fasilitator mengulang kembali, dengan metode ini diajarkan teknik membaca kritis.

Pertemuan pertama sampai akhir sudah dilakukan. Jumlah pertemuan sebanyak empat sesi. Siswa nampak antusias dalam proses belajar di kelas. Membaca kritis dapat membantu siswa dan guru untuk menghindari kebosanan belajar di kelas.

Nilai rata-rata pemahaman karakter sebelum membaca kritis lebih kecil daripada setelah membaca kritis. Hal ini menandakan bahwa membaca kritis dapat membantu pemahaman karakter siswa.

Nilai rata-rata pemahaman karakter kelas sebelum membaca kritis sebesar 65, sedangkan nilai rata-rata kelas setelah membaca kritis sebesar 78. Dapat digambarkan pada bagan di bawah ini;

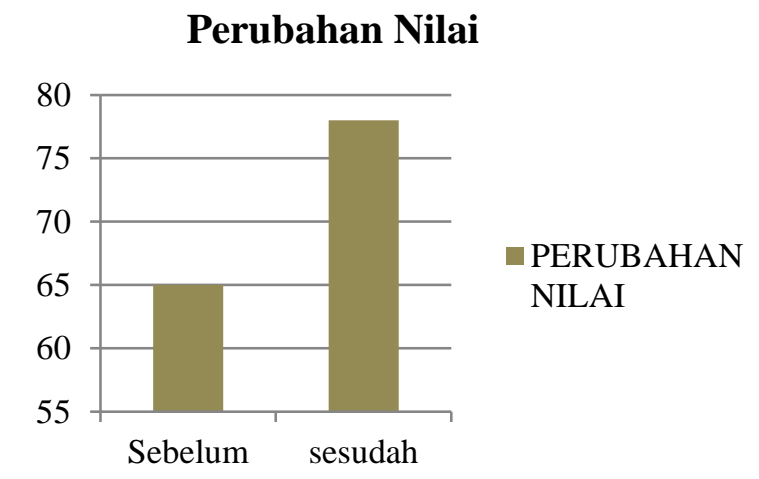

Gambar 1. Hasil sebelum dan sesudah membaca kritis

Pada bagan di atas terlihat kenaikan nilai sebesar 13 poin. Hal ini ditunjukkan dengan nilai sebelum membaca kritis yaitu 65 dan sesudahnya sebesar 78. Hal ini menandakan bahwa membaca kritis dapat membantu pembelajaran di sekolah. 
KANGMAS: Karya Ilmiah Pengabdian Masyarakat, 1 (1), March 2020 - 12

http://journal.neolectura.com/index.php/Kangmas

\section{SIMPULAN}

Kegiatan pengabdian masyarakat yang dilakukan ini sangat perlu dan

Vol. 1, No. 1,

MARCH

2020,

pp. $8-12$

e-ISSN:

XXXX-XXXX

Title

Character

Development

for Class IX

Students

through

Critical

Reading

Activities at

MTs Nurul

Hikmah and

Driewanti

Middle School

Bekasi, West

Java

Author

Nicky Rosadi ${ }^{1}$,

Priyono²,

Sigit Widiyarto $^{3}$ dirasakan manfaat bagi peningkatan proses belajar mengajar di sekolah. Kegiatan ini juga memberikan kontribusi yang positif untuk menciptakan pembelajaran yang optimal. Kegiatan ini telah berjalan dengan baik dan dapat disimpulkan sebagai berikut:

1. Siswa-siswi menjadi lebih termotivasi, dan memiliki ide dan gagasan dalam menanggapi suatu informasi.

2. Siswa lebih kritis dalam menyerap sebuah informasi

Dari simpulan di atas, kami mengajukan beberapa saran sebagai berikut:

1. Siswa hendaknya diberi arahan dalam menyerap informasi yang didapatkan.

2. Siswa diharapkan lebih kritis dalam mendapatkan sebuah informasi.

3. Kerja sama yang baik dan berkesinambungan perlu dilakukan antarlembaga sekolah, baik kepala sekolah, guru, pengawas, orang tua, dan para siswa

\section{DAFTAR PUSTAKA}

Abidin, Y. (2012). Pembelajaran Membaca Berbasis Pendidikan Karakter. Bandung: PT Refika Aditama.

Adler, M. J. \& Charles. (2007). How to Read a Book: Cara Mencapai Puncak Tujuan Membaca. Jakarta: iPublishing.

Alwasilah, C. (2009). Filsafat Bahasa dan Pendidikan. Bandung: PT Remaja Rosdakarya.

Chaffee, J. (2010). Thinking Critically. 10th edition. Boston: Wardsworth.

Seyler, D. U. (2008). Read, Reason,Write: An Argument Text and Reader. 8th edition. New York: McGraw-Hill.

Smaldino, S. E., Lowther, D. L., \& Russel, J. D. (2011). Instructional Technology \& Media for Learning: Teknologi Pembelajaran dan Media untuk Belajar. Jakarta: Kencana.

Spears, D. (2006). Developing Critical Reading Skills. 7th edition. New York: McGrawhill.

Wallace, M. \& Wray, A. (2011). Critical Reading and Writing for Postgraduates. London: SAGE Publications Ltd. MTs Nurul Hikmah and Driewanti Middle School Bekasi, West Java. KANGMAS: Karya Ilmiah Pengabdian Masyarakat, 1 (1). 8-12 